\title{
Association of the Psychological Distress and Cardiovascular Risk Behaviors, Conditions and Diseases: the CroHort Study
}

\author{
Tea Vukušić Rukavina, Ognjen Brborović, Hana Fazlić, Slavica Sović and Marta Čivljak \\ University of Zagreb, School of Medicine, »Andrija Štampar« School of Public Health, Zagreb, Croatia
}

\begin{abstract}
A B S T R A C T
Aim of this study was to explore and compare association of PD (psychological distress) and cardiovascular risk behaviors, conditions and diseases in Croatian adult population. The sample of this study consisted of 3,229 respondents. Psychological distress status was measured by the five-item Mental Health Scale (MHI-5) of the Short Form questionnaire (SF-36), hence one distinguished subgroup consisted of population with PD and other without PD. Prevalence of cardiovascular risk behaviors, cardiovascular risk conditions and self-reported cardiovascular diseases within each subgroup were calculated. During the follow up period physical inactivity remained the only risk behavior showing significant difference between PD status subgroups for both genders demonstrating higher prevalence in men and women with PD. During follow up period hypertension, myocardial infarction, angina pectoris and self-reported heart failure in women remained constant in showing statistically significant prevalence difference among population with and without $P D$. In men that type of constant association was shown only for heart failure.
\end{abstract}

Key words: psychological distress, cardiovascular disease, risk factors, health behavior, CroHort study

\section{Introduction}

Psychological distress (PD) is a non-specific dimension of psychopathology, indicating that something is wrong but does not yield diagnostic assessment, comprised usually of anxiety and depression related distress states $^{1}$. The link between psychological distress and cardiovascular disease (CVD) has been identified as an important public health issue ${ }^{2-5}$.

Behavioral changes, such as increased smoking, reduced physical activity and poor dietary habits may occur as an adaptation or coping response to psychological distress, thus are potentially important intermediate factors in disease processes ${ }^{6-8}$. Besides cardiovascular risk behaviors, cardiovascular risk conditions such as high blood pressure, outsized waist circumference and BMI $\geq$ 30 , that are possible consequences of cardiovascular risk behaviors have also been associated with higher risks for $\mathrm{CVD}^{9-11}$. The presence of psychological distress, measured with screening instruments such as the General Health Questionnaire (GHQ) or Mental Health Scale (MHI-5) of the Short Form questionnaire (SF-36), has been associated with incident CVD in several prospective cohort studies ${ }^{12-14}$ with effect sizes that are comparable to conventional risk factors such as hypertension, obesity, and physical inactivity ${ }^{7,15}$. Aim of this study was to explore and compare association of psychological distress and cardiovascular risk behaviors, risk conditions and diseases for population cohort from Croatian Adult Health Cohort Study (CroHort).We have also explored and compared association's strength obtainable as relative risk of psychological distress on three levels: cardiovascular risk behaviors, conditions and diseases.

\section{Materials and Methods}

\section{Sample}

This study was a part of the Croatian Adult Health Cohort Study (CroHort), a repeated cross-sectional survey of adults aimed at providing a comprehensive community health assessment of Croats, including their access to and use of health care services, health status, and determinants of health such as nutrition, physical activ- 
ity, smoking and alcohol consumption. The sample was first examined in the 2003 Croatian Adult Health Survey $(\mathrm{CAHS})^{16}$ and re-examined in the 2008 CroHort $^{17}$. The sample of this study consisted of 3,229 respondents (1,015 male and 2,214 female) who participated in both Croatian Adult Health Survey 2003 and the follow-up Croatian Adult Health Cohort Study (CroHort) in 2008. They were 18 years or older at the time of the first survey. Respondents who participated in 2003 , but died before 2008 survey were not included in the analysis (808 respondents). Further details on this sample were described elsewhere ${ }^{17}$.

\section{Variables}

In this study complete survey sample, a total of 3,229 respondents were divided in two subgroups according to the psychological distress status. Psychological distress status was measured by the five-item Mental Health Scale of the SF-36 (MHI-5) ${ }^{18,19}$ hence one distinguished subgroup consisted of population with psychological distress and other without psychological distress. MHI-5 is a well validated and reliable measure of mental health status $^{20}$. MHI-5 has been used to identify mental disorders in the community ${ }^{21}$ and clinical samples ${ }^{22-26}$. The MHI-5 used in CroHort is part of the SF-36 version 2 and comprises five questions relating to the past four weeks: »Have you been very nervous? « "Have you felt so down in the dumps that nothing could cheer you up? « "Have you felt calm and peaceful? « »Have you felt down-hearted and depressed? « »Have you been happy? « Each of the five questions has five response categories which are scored from 1 to 5 : "all of the time 1 ; "most of the time 2 ; »some of the time 3 ; »a little of the time 4 ; or »none of the time " 5 . Response scores were transformed and imputed missing data to a scale of range 0 to $100 \mathrm{using}$ the standard method of the SF Health Outcomes Scoring Software Ver.1.0.1.19. Lower scores on MHI-5 indicate lower mental health status. Psychological distress was determined when MHI-5 score was less or equal to $52^{27-29}$.

Variables defining cardiovascular risk behaviors used in this paper are smoking, physical inactivity, unhealthy nutrition and heavy alcohol consumption. Variables defining cardiovascular risk conditions are high blood pressure, outsized waist circumference and body mass index. Details of construction of cardiovascular risk behaviors and risk conditions are reported elsewhere ${ }^{16}$, with the exception of defining variable overweight as of those having BMI $\geq 30$. Three self-reported cardiovascular disease diagnoses were examined: angina pectoris (AP), myocardial infarction (MI) and heart failure (HF). Every variable was transformed as dichotomous where 1 means risk while 0 is without risk. Each subgroup, with or without $\mathrm{PD}$, was then divided and analyzed separately according to gender.

\section{Statistical analysis}

The analysis included calculations of the prevalence of cardiovascular risk behaviors, cardiovascular risk conditions and self-reported cardiovascular diseases within each subgroup. 95\% confidence intervals (CI) were calculated as well and compared within subgroups according to PD status regarding gender for 2003 and 2008 data. P values less than 0.05 were considered statistically significant. All statistical analyses were carried out with the SAS statistical package ver. 9.1.

As a measure of association strength between variables and PD status relative risks were calculated as a simple ratio between characteristic prevalence of population with and without PD.

\section{Results}

A total of 3,229 participants (31.4\% male and $68.6 \%$ female) were included in the study. Prevalence of cardiovascular risk behaviors, cardiovascular risk conditions and self-reported cardiovascular diseases regarding genders according to PD status for 2003 and 2008 are presented in Tables 1 and 2 . In men among analyzed risk behavior variables in 2003, physical inactivity and heavy alcohol consumption were showing statistically significant differences in prevalence between population with and without PD. In women, smoking and physical inactivity showed significant differences in prevalence between PD status subgroups. During the follow up period physical inactivity remained the only risk behavior showing significant difference between PD status subgroups for both genders demonstrating higher prevalence in men and women with PD.

Among prevalences of cardiovascular risk conditions there was no statistical difference for any of the conditions between men with and without PD, both in 2003 and 2008. In women high blood pressure and waist $\geq 88$ $\mathrm{cm}$ showed significant differences in prevalence between PD status subgroups in 2003. In 2008 the significant difference is present only for the hypertension (women with PD 51.6\%, women without PD 40.0\%).

The most consistent statistically significant differences between population with and without $\mathrm{PD}$, both in 2003 and 2008, are among analyzed self-reported CVD. Women with PD have statistically significant higher prevalences of AP, MI and HF in 2003 and 2008. In 2003 men with PD had significantly higher prevalences of MI and $\mathrm{HF}$, during follow up the significant difference remained only for the self-reported HF (men with PD 28.9\%, men without PD 14.8\%).

Trends in prevalence changes of cardiovascular risk behaviors, risk conditions and self-reported CVD regarding genders according to PD status for 2003 and 2008 are presented in Figures 1 and 2. In women without PD there is statistically significant increase of alcohol consumption from 0.8 to $3.5 \%$ and waist $\geq 88 \mathrm{~cm}$ from 56.6 to $67.9 \%$. In men without PD no statistical significant change of prevalences for any of the risk factors, conditions or CVD was observed. During the study differences between genders were found, both in 2003 and 2008, for smoking, heavy alcohol consumption, unhealthy nutrition and high blood pressure men having higher preva- 
TABLE 1

PREVALENCES OF CARDIOVASCULAR RISK BEHAVIORS, CONDITIONS AND DISEASES IN 2003

\begin{tabular}{|c|c|c|c|c|}
\hline & \multicolumn{2}{|c|}{ Population without PD } & \multicolumn{2}{|c|}{ Population with PD } \\
\hline & Prevalence (\%) & $95 \% \mathrm{CI}$ & Prevalence (\%) & $95 \% \mathrm{CI}$ \\
\hline \multicolumn{5}{|l|}{ Risk behaviors } \\
\hline \multicolumn{5}{|l|}{ Men } \\
\hline Smoking & 24.9 & $21.7-28.0$ & 22.7 & $17.9-27.6$ \\
\hline Physically inactive & 28.1 & $24.9-31.4$ & 46.4 & $40.6-52.1$ \\
\hline Unhealthy nutrition & 16.5 & $13.8-19.2$ & 23.2 & $18.3-28.0$ \\
\hline Heavy alcohol consumption & 11.6 & $9.0-14.1$ & 22.6 & $17.0-28.3$ \\
\hline \multicolumn{5}{|l|}{ Women } \\
\hline Smoking & 16.5 & $14.7-18.4$ & 12.1 & $9.7-14.6$ \\
\hline Physically inactive & 30.3 & $27.9-32.6$ & 41.7 & $38.1-45.3$ \\
\hline Unhealthy nutrition & 11.1 & $9.5-12.7$ & 15.1 & $12.4-17.7$ \\
\hline Heavy alcohol consumption & 0.8 & $0.2-1.4$ & 1.7 & $0.2-3.3$ \\
\hline \multicolumn{5}{|l|}{ Risk conditions } \\
\hline \multicolumn{5}{|l|}{ Men } \\
\hline High blood pressure & 51.0 & $46.4-53.7$ & 58.3 & $52.3-63.7$ \\
\hline Waist $\geq 102 \mathrm{~cm}$ & 43.0 & $39.4-46.6$ & 48.6 & $42.8-54.4$ \\
\hline $\mathrm{BMI} \geq 30$ & 28.1 & $21.0-30.0$ & 27.9 & $21.0-29.0$ \\
\hline \multicolumn{5}{|l|}{ Women } \\
\hline High blood pressure & 39.8 & $37.3-42.3$ & 53.3 & $49.7-57.0$ \\
\hline Waist $\geq 88 \mathrm{~cm}$ & 56.6 & $54.1-59.1$ & 69.8 & $66.4-73.2$ \\
\hline $\mathrm{BMI} \geq 30$ & 38.4 & $32.5-45.2$ & 30.4 & $27.8-33.5$ \\
\hline \multicolumn{5}{|l|}{ Self-reported CVD } \\
\hline \multicolumn{5}{|l|}{ Men } \\
\hline Myocardial infarction & 4.5 & $3.0-6.1$ & 10.7 & $7.2-14.3$ \\
\hline Angina pectoris & 6.2 & $4.5-8.0$ & 10.4 & $7.2-14.3$ \\
\hline Heart failure & 12.3 & $9.9-14.7$ & 28.9 & $26.1-36.8$ \\
\hline \multicolumn{5}{|l|}{ Women } \\
\hline Myocardial infarction & 2.1 & $1.3-2.8$ & 5.6 & $3.9-7.3$ \\
\hline Angina pectoris & 3.7 & $2.8-4.7$ & 10.8 & $8.6-13.1$ \\
\hline Heart failure & 13.3 & $11.6-15.0$ & 32.4 & $29.0-35.8$ \\
\hline
\end{tabular}

lences than women; women having higher prevalences of $\mathrm{BMI} \geq 30$ and waist circumference.

Among CVD, in 2003 statistically significant difference was observed for MI (men $4.5 \%$, women $2.1 \%$ ), but although prevalence of MI increased, the difference between genders is no longer significant in 2008 (men $5.8 \%$, women $3.2 \%$ ). In 2008 the statistically significant difference was found for prevalence of $\mathrm{AP}$ (men $8.0 \%$, women $4.3 \%$, Figure 1 ).

In woman with PD there is statistically significant decrease of unhealthy nutrition to $9.5 \%$ during follow up period. Woman with PD show substantial increase (where $95 \% \mathrm{CI}$ are overlapping slightly) in smoking from 12.1 to $17.2 \%$; and in physical inactivity from 41.7 to $48.2 \%$. In men with $\mathrm{PD}$ no statistical significant change of prevalences for any of the risk factors, conditions or diseases was observed, but the decrease of high blood pressure from 58.3 to $47.1 \%$ should be emphasized. During the study statistically significant differences between genders were found, both in 2003 and 2008, for smoking, heavy alcohol consumption, unhealthy nutrition men having higher prevalences than women; and for waist circumference where woman have higher prevalence. During the study, in population with PD regarding gender, no statistically significant changes of prevalences were observed for self-reported CVD.

Figure 3 presents relative risks regarding genders of having one of cardiovascular risks behaviors, conditions or diseases and psychological distress for the baseline and follow up period. Cardiovascular diseases remained to have the highest relative risks of all measured variables, although relative risks for CVD in 2008 have decreased. Women with psychological distress are having consistently higher relative risks for all diseases than men. The highest measured relative risk of CVD is for AP (men 1.55; women 2.44), than relative risk for $\mathrm{HF}$ (men 1.95; women 2.32) while for MI relative risk is the lowest (men 1.71; women 1.91) but still higher than relative risks for behaviors and conditions. 
TABLE 2

PREVALENCES OF CARDIOVASCULAR RISK BEHAVIORS, CONDITIONS AND DISEASES IN 2008

\begin{tabular}{|c|c|c|c|c|}
\hline & \multicolumn{2}{|c|}{ Population without PD } & \multicolumn{2}{|c|}{ Population with PD } \\
\hline & Prevalence $(\%)$ & $95 \% \mathrm{CI}$ & Prevalence (\%) & $95 \% \mathrm{CI}$ \\
\hline \multicolumn{5}{|l|}{ Risk behaviors } \\
\hline \multicolumn{5}{|l|}{ Men } \\
\hline Smoking & 19.8 & $16.7-23.0$ & 23.1 & $18.3-27.9$ \\
\hline Physically inactive & 32.5 & $29.0-36.1$ & 45.5 & $40.1-50.8$ \\
\hline Unhealthy nutrition & 16.5 & $13.7-19.3$ & 17.0 & $13.0-21.0$ \\
\hline Heavy alcohol consumption & 13.2 & $10.4-16.0$ & 17.2 & $12.6-21.8$ \\
\hline \multicolumn{5}{|l|}{ Women } \\
\hline Smoking & 17.4 & $15.3-19.4$ & 17.2 & $14.3-20.2$ \\
\hline Physically inactive & 32.9 & $30.5-35.3$ & 48.2 & $44.7-51.8$ \\
\hline Unhealthy nutrition & 10.1 & $8.6-11.7$ & 9.5 & $7.4-11.6$ \\
\hline Heavy alcohol consumption & 3.5 & $2.3-4.6$ & 3.9 & $2.2-5.7$ \\
\hline \multicolumn{5}{|l|}{ Risk conditions } \\
\hline \multicolumn{5}{|l|}{ Men } \\
\hline High blood pressure & 51.0 & $47.2-54.8$ & 47.1 & $41.7-52.5$ \\
\hline Waist $\geq 102 \mathrm{~cm}$ & 47.9 & $44.0-51.8$ & 45.5 & $40.0-51.0$ \\
\hline $\mathrm{BMI} \geq 30$ & 24.7 & $21.4-27.9$ & 26.7 & $21.9-31.5$ \\
\hline \multicolumn{5}{|l|}{ Women } \\
\hline High blood pressure & 40.0 & $37.5-42.6$ & 51.6 & $48.0-55.2$ \\
\hline Waist $\geq 88 \mathrm{~cm}$ & 67.9 & $65.4-70.4$ & 72.8 & $69.5-76.1$ \\
\hline $\mathrm{BMI} \geq 30$ & 34.4 & $32.0-36.9$ & 33.3 & $29.9-36.8$ \\
\hline \multicolumn{5}{|l|}{ Self-reported CVD } \\
\hline \multicolumn{5}{|l|}{ Men } \\
\hline Myocardial infarction & 5.8 & $4.0-7.6$ & 9.9 & $6.6-13.2$ \\
\hline Angina pectoris & 8.0 & $5.9-10.0$ & 12.3 & $8.8-15.9$ \\
\hline Heart failure & 14.8 & $12.1-17.6$ & 28.9 & $23.9-33.8$ \\
\hline \multicolumn{5}{|l|}{ Women } \\
\hline Myocardial infarction & 3.2 & $2.3-4.2$ & 6.2 & $4.4-7.9$ \\
\hline Angina pectoris & 4.3 & $3.2-5.4$ & 10.5 & $8.3-12.8$ \\
\hline Heart failure & 12.3 & $10.6-14.0$ & 28.5 & $25.2-31.8$ \\
\hline
\end{tabular}

\section{Discussion}

The study results suggest that psychological distress is a burden among participants with various cardiovascular risks, conditions and diseases. There are several potential pathways for the effect of PD on CVD but two are referenced most often. First, PD may be indirectly associated with CVD through associations with the adoption of unhealthy behaviors such as smoking, unhealthy diet, heavy alcohol consumption and physical inactivity, which in themselves increase risk of CVD. Second PD may have direct effect on CVD independent of other behavioral and psychosocial factors mediated other by neuro-humoral or by metabolic disturbance ${ }^{14}$. Data from the Scottish study suggest that the behavioral factors of smoking and physical activity made the largest contribution to increased risk of cardiovascular events ${ }^{30}$. Ferketich and Binkley showed in a study on US population strong correlation between PD and current smoking, physical activity and hypertension while in our study results for smoking do not confirm previous findings ${ }^{31}$. Our study showed that for women relative risk of being smoker and having $\mathrm{PD}$ is almost equal to one, but there is a trend of increase in this risk factor's association with the PD. In men, smoking has relative risk of 1.16 .

Physical inactivity is proven as a risk factor both for CVD and $\mathrm{PD}^{14}$. This study confirms the previously established connections between PD and physical activity ${ }^{15,30}$. When we've compared risk factors for 2003 and 2008 data, physical inactivity in women remained the only risk factor showing statistically significant prevalence difference between population with and without PD. Relative risks of having $\mathrm{PD}$ and being physically inactive is the highest among all risk factors for both men and women in follow up. Although causality remains unclear we would suggest that physical inactivity seems to be major risk behavior in Croatian population for PD. That applies especially for women. These findings can serve as a basis for development of the health prevention programs that will include increased physical activity with 


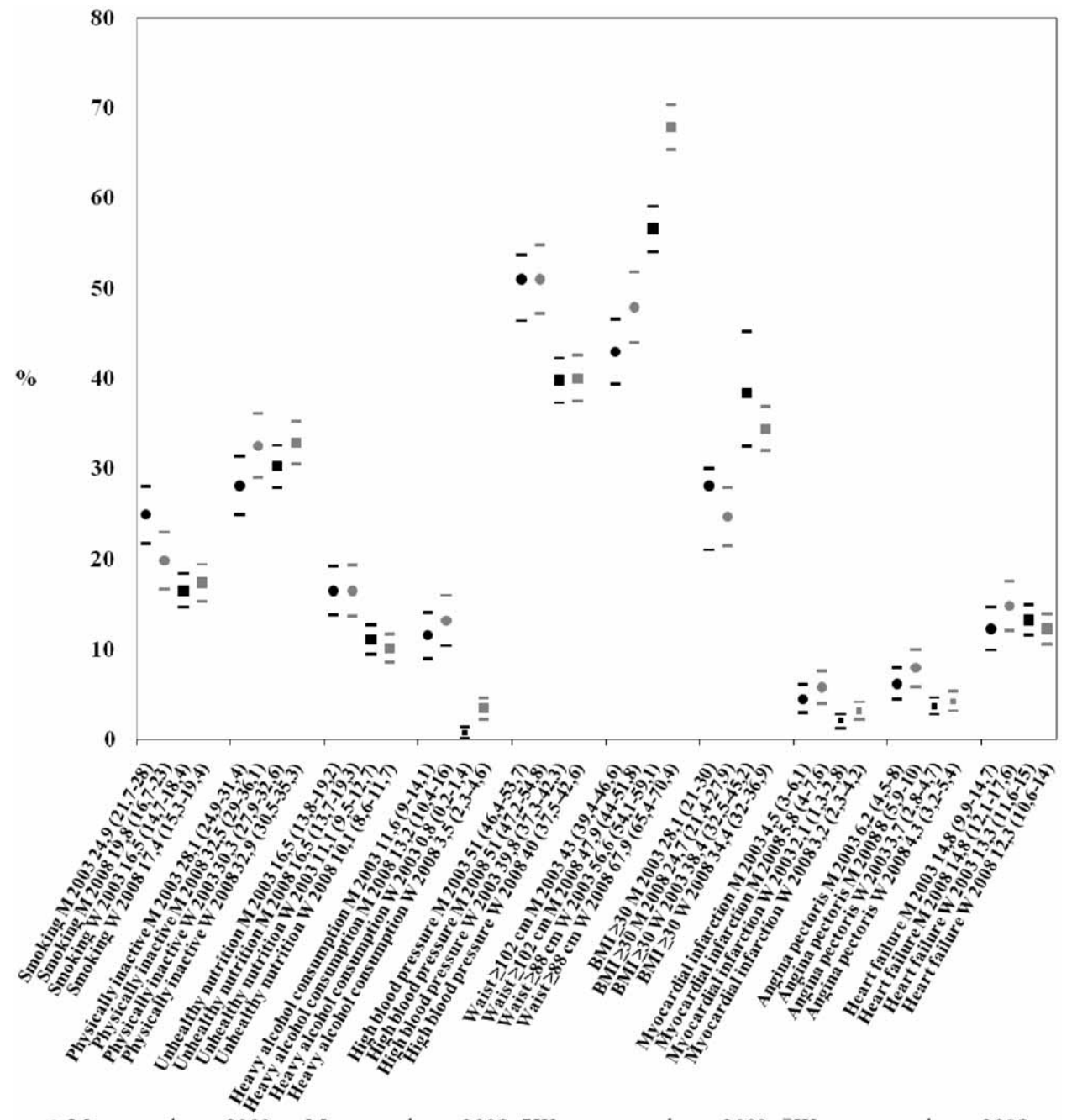

- Men prevalence 2003; • Men prevalence 2008; -Women prevalence 2003; "Women prevalence 2008;

$$
\text { - \& - } 95 \% \text { Confidence interval }
$$

Fig. 1. Prevalence changes of risk behavior, condition and disease in population without psychological distress. $M-m e n ; W-$ women.

benefits on physical and mental health of the targeted population.

Numerous studies have determined association among $\mathrm{PD}$ and alcohol consumption ${ }^{30,32-34}$. We've examined effects of heavy alcohol consumption on mental health in a Croatian population and our results haven't showed statistically significant differences regarding PD status. The increase of heavy alcohol consumption prevalence that was observed in women in both PD subgroups (from 0.8 to $3.5 \%$ in women without PD; from 1.7 to $3.9 \%$ in women with PD) can be explained by more sincere answers during the follow up about the real alcohol intake than actual increase.

According to American Heart Association of major importance for CVD are nutrients like vegetables, fruits, whole-grain products and fat-free or low-fat dairy products and low salt intake ${ }^{35}$. Our results did not prove association between PD and unhealthy diet, neither for wo- men nor for men. Women with PD have significant decrease in unhealthy nutrition in follow up period (from 15.1 to $9.5 \%$ ) which can be explained by older respondents that are more aware of dietary restrictions.

Cardiovascular conditions are more reliable determinants for CVD than cardiovascular risk behaviors since it is accepted that risk behaviors are precursor of cardiovascular conditions although causality is much more complex. Our study also confirms that psychological distress was associated with a higher prevalence of hypertension that partly mediated the greater risk of CVD event $^{30}$. Similar to physical inactivity, during follow up period, high blood pressure in women remained the only risk condition showing statistically significant prevalence difference among population with and without PD. Interestingly the prevalence of high blood pressure in men with PD decreased from 58.3 to $47.7 \%$ becoming even smaller than the prevalence of high blood pressure in men without PD (51.1\%). 


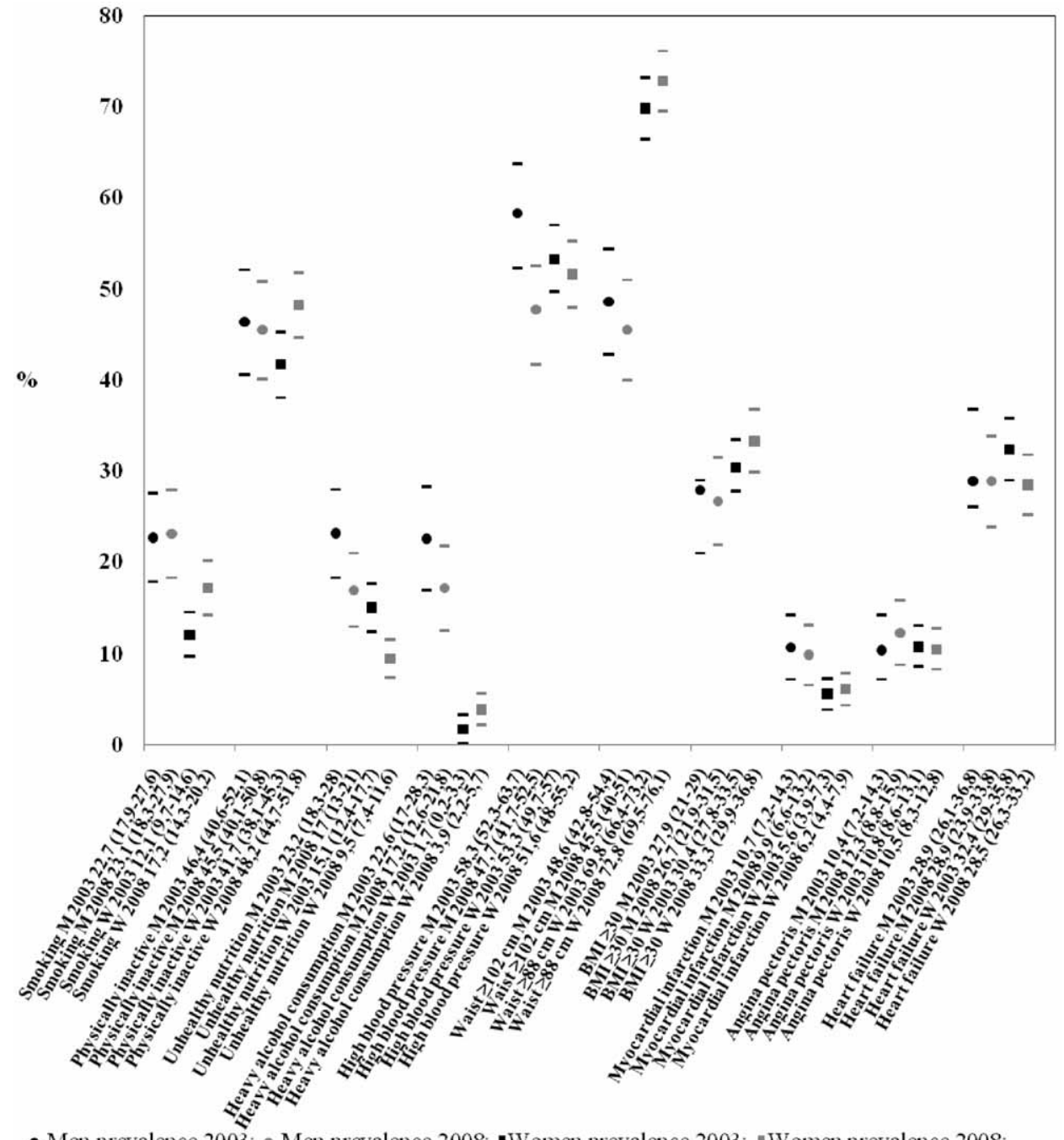

- Men prevalence 2003; • Men prevalence 2008; -Women prevalence 2003; "Women prevalence 2008; - \& - 95\% Confidence interval

Fig. 2. Prevalence changes of risk behavior, condition and disease in population with psychological distress. M-men; $W$-women.

Answer to the main question whether $\mathrm{PD}$ is related to CVD is given without uncertainties in Figure 3. Contrary to the findings of Puustinen et al. that highlight the importance of identifying men with psychological distress when assessing CVD risk ${ }^{36}$, our study shows that association between CVD and PD is stronger in women. Similar results have been reported by Stansfeld et al. ${ }^{14}$ demonstrating a significant association in women between psychological distress and self-reported coronary heart disease. The strength of this association is not doubtable since relative risk of having $\mathrm{PD}$ and CVD is higher for each of the CVD variables than in population without $\mathrm{PD}$, both in baseline and follow up period. Relative risks decreased somewhat in the follow up period, but still results of the study are consistent for all CVD, with angina pectoris having highest relative risk 2.44 . In men association between $\mathrm{PD}$ and self-reported CVD is proven for heart failure (relative risk 1.95).
Limitation of this study is self-reporting of CVD. Also results should be interpreted with acknowledged limitation of the follow-up sample where respondents were significantly older than non-respondents ${ }^{17}$ which might influence the results. Another limitation is that sample of CroHort was not weighted; therefore data from CroHort should be considered informative and analyzed only on national level. Although this study was a part of a cohort survey, our research did not analyze data on mortality. Thus, the direction of causation between psychological distress and CVD risk remains unclear: various biological and behavioral factors associated with psychological distress may increase CVD risk, but variables that were not included in the CVD risk factors - such as age, socio-economic status and diabetes - may also be causally related to future psychological distress. In order to limit findings on those most important, authors have intentionally excluded age and socioeconomic determinants 


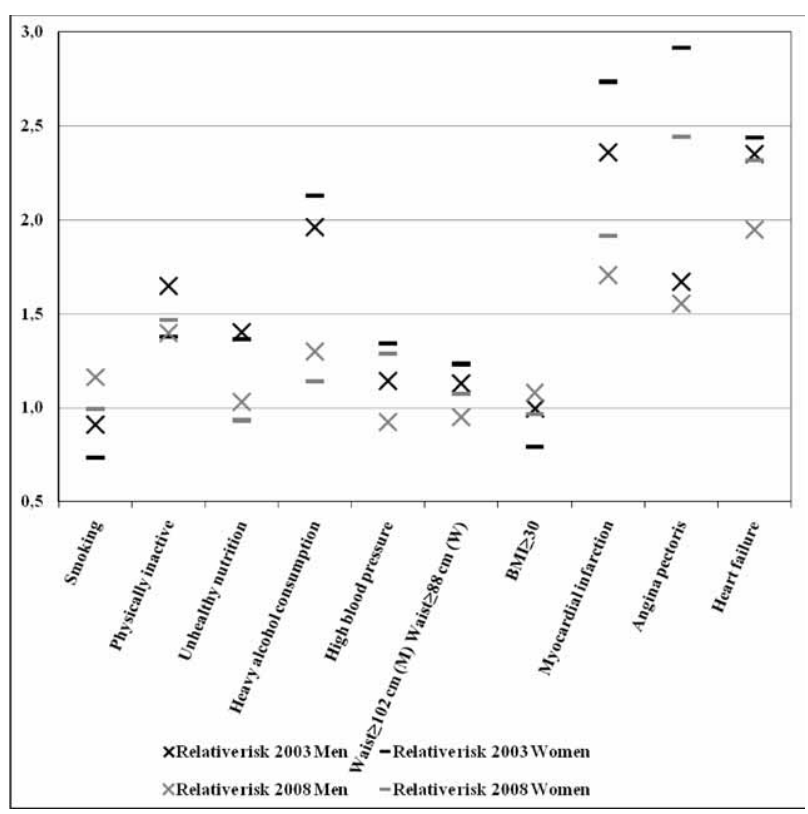

Fig. 3. Relative risks plot of having one of cardiovascular risks behaviors, conditions, diseases and psychological distress.

from statistical analysis although it is clear that in further study it is necessary to include them. Major reason for including age in analysis is time needed to develop CVD following suggested pathway cardiovascular risk behavior-condition-disease, while socioeconomic determinants (e.g. education) are among major factors involved in development of health inequalities and PD.

\section{Conclusion}

The study results suggest that psychological distress is a burden among participants with various cardiovascular risks, conditions and diseases. During the follow up period physical inactivity remained the only risk behavior showing significant difference between PD status subgroups for both genders demonstrating higher prevalences in men and women with PD. Association between $\mathrm{PD}$ and cardiovascular conditions and diseases is stronger in women than in men. During follow up period hypertension, self-reported myocardial infarction, angina pectoris and heart failure in women remained constant in showing statistically significant prevalence difference among population with and without PD. In men that type of constant association was shown only for heart failure. Causality of association between cardiovascular conditions and diseases and psychological distress remains yet to be investigated in further studies.

\section{Acknowledgements}

This study was supported by the Croatian Ministry of Science, Education and Sport, Grant No. 108-10801350264.

\section{R E F E R E N C E S}

1. DOHRENWEND BP, SHROUT PE, EGRI G, MENDELSOHN FS, Arch Gen Psychiatry, 37 (1980). — 2. NABI H, SINGH-MANOUX A, SHIPLEY M, GIMENO D, MARMOT MG, KIVIMAKI M, Arterioscler Thromb Vasc Biol, 28 (2008). - 3. HEMINGWAY H, MARMOT M, BMJ, 318 (1999). - 4. RASUL F, STANSFELD SA, SMITH GD, SHLOMO YB, GALLACHER J, Psychol Med, 37 (2007). - 5. BROTMAN DJ, GOLDEN SH, WITTSTEIN IS, Lancet, 370 (2007). - 6. STEPTOE AEA, Depression and Physical Illness (Cambridge University Press, Cambridge, 2007). 7. YUSUF S, HAWKEN S, OUNPUU S, DANS T, AVEZUM A, LANAS F MCQUEEN M, BUDAJ A, PAIS P, VARIGOS J, LISHENG L, Lancet, 364 (2004). - 8. BRBOROVIC O, RUKAVINA TV, PAVLEKOVIC G, DZAKULA A, SOGORIC S, VULETIC S, Coll Antropol, 33 Suppl 1 (2009). — 9. VULETIC S, KERN J, IVANKOVIC D, POLASEK O, BRBOROVIC O, Acta Med Croatica, 61 (2007). - 10. CHEN HJ, BAI CH, YEH WT, CHIU HC, PAN WH, Stroke, 37 (2006). - 11. FARMER JA, Current cardiology reports, 6 (2004) 427. - 12. ROBINSON KL, MCBETH J, MACFARLANE GJ, Ann Epidemiol, 14 (2004). - 13. MAY M, MCCARRON P, STANSFELD S, BEN-SHLOMO Y, GALLACHER J, YARNELL J, DAVEY SMITH G, ELWOOD P, EBRAHIM S, Stroke, 33 (2002). - 14. STANSFELD SA, FUHRER R, SHIPLEY MJ, MARMOT MG, Int J Epidemiol, 31 (2002). 15. MUHSEN K, GARTY-SANDALON N, GROSS R, GREEN MS, Prev Med, 50 (2010). - 16. VULETIC S, POLASEK O, KERN J, STRNAD M, BAKLAIC Z, Coll Antropol, 33 Suppl 1 (2009). - 17. IVIČEVIĆ-UHERNIK A, VULETIĆ S, KERN J, DEĆKOVIĆ-VUKRES V, MIHEL S, ERCEG M, PRISTAŠA I, Coll Antropol, 36 Suppl 1. (2012) 3. - 18. BER WICK DM, MURPHY JM, GOLDMAN PA, WARE JE, JR., BARSKY AJ,

WEINSTEIN MC, Med Care, 29 (1991). - 19. WARE JE, Spine, 25 (2000) 3130. - 20. WARE JE, JR., GANDEK B, J Clin Epidemiol, 51 (1998). 21. GILL SC, BUTTERWORTH P, RODGERS B, MACKINNON A, Psychiatry Res, 152 (2007). — 22. RUMPF HJ, MEYER C, HAPKE U, JOHN U, Psychiatry Res, 105 (2001). — 23. WINSTON M, SMITH J, Soc Psychiatry Psychiatr Epidemiol, 35 (2000). - 24. FRIEDMAN B, HEISEL M, DELAVAN R, J Am Geriatr Soc, 53 (2005). - 25. MEANS-CHRISTENSEN AJ, ARNAU RC, TONIDANDEL AM, BRAMSON R, MEAGHER MW, J Behav Med, 28 (2005). - 26. KELLY MJ, DUNSTAN FD, LLOYD K, FONE DL, BMC Psychiatry, 8 (2008). - 27. HOLMES WC, Med Care, 36 (1998). - 28. KOVESS V. The State of Mental Health in European Union. Luxembourg: European Commission, Directorate General for Health and Consumer Protection; 2004. - 29. (EORG) TEORG. Eurobarometer 58. 2. The mental health status of the European population; 2003. - 30. HAMER M, MOLLOY GJ, STAMATAKIS E, J Am Coll Cardiol, 52 (2008). 31. FERKETICH AK, BINKLEY PF, Eur Heart J, 26 (2005). - 32. MAL YUTINA S, BOBAK M, KURILOVITCH S, GAFAROV V, SIMONOVA G, NIKITIN Y, MARMOT M, Lancet, 360 (2002). - 33. HOLDEN L, SCUFFHAM P, HILTON M, VECCHIO N, WHITEFORD H, Aust N Z J Public Health, 34 (2010). — 34. OHIRA T, J Epidemiol, 20 (2010). — 35. ASSOCIATION AH, Our 2006 Diet and Lifestyle Recommendations. accessed 05. June 2008.2008 Available from: URL: http://www.americanheart.org/ presenter.jhtml?identifier $=851$. -36 . PUUSTINEN PJ, KOPONEN H KAUTIAINEN H, MANTYSELKA P, VANHALA M, Scand J Prim Health Care, 28 (2010). 


\section{T. Vukušić Rukavina}

University of Zagreb, School of Medicine, »Andrija Štampar« School of Public Health, Rockefellerova 4, 10000 Zagreb, Croatia

e-mail:tvukusic@snz.hr

\section{POVEZANOST PSIHOLOŠKE PATNJE I KARDIOVASKULARNIH RIZIČNIH PONAŠANJA, STANJA I BOLESTI: CroHort STUDIJA}

\section{S A Ž E T A K}

Cilj ovoga istraživanja bio je istražiti i usporediti povezanost psihološke patnje (PP) i kardio-vaskularnih bolesti (KVB) u odrasloj populaciji Hrvatske. Također smo istraživali snagu povezanosti putem relativnog rizika za PP na tri razine: kardiovaskularnih rizičnih ponašanja, stanja i bolesti, te njihovu promjenu tijekom vremena. Postojanje PP procijenjeno je temeljem Skale mentalnog zdravlja koja je dio SF-36 upitnika. Kompletan uzorak je podijeljen u dvije podgrupe, prva s PP, a druga bez PP. Rezultati istraživanja pokazuju da je psihološka patnja breme sudionicima u odnosu na kardiovaskularna rizična ponašanja, stanja i bolesti. Tijekom prve i druge faze kohorte tjelesna neaktivnost ostala je jedino rizično ponašanje sa statistički značajnom razlikom za oba spola s višim prevalencijama u osoba s psihološkom patnjom. Povezanost PP i kardiovaskularnih stanja i bolesti izraženija je za žene. Sve KVB konzistentno su povezane s većim relativnim rizikom za PP u žena, dok se kod muškaraca s PP i bez PP statistički značajna razlika zadržala samo za zatajenje srca. 